June - 2009

\title{
Preferences of Residents in Four Northern Alberta Communities Regarding Local Post-Secondary Programming
}

\author{
Patrick J. Fahy and Nancy Steel \\ Athabasca University, Canada \\ Patricia Martin \\ Banshee Consulting, Canada
}

\begin{abstract}
The western Canadian province of Alberta has used some of the proceeds from exploitation of its extraordinary natural resources to make available a range of post-secondary training and education opportunities to residents. While these provisions appear comprehensive, this study examined how well they actually suit the express needs of the residents of remote, Northern areas of the province, many of them Aboriginal.
\end{abstract}

The literature shows that while Aboriginal people are underrepresented in Canada in university enrollments, they are no longer underrepresented in college or other institutions, suggesting that gains have been made for some residents of rural and remote parts of Canada. Further, when Northern residents (especially Aboriginal males) complete advanced training, Statistics Canada reports they are highly successful in employment and income. Access is the pivotal issue, however: leaving the local community to attend training programs elsewhere is often disruptive and unsuccessful. As will be seen, the issue of access arose in this study's findings with direct implications for distance delivery and support.

This study was conducted as part of Athabasca University's Learning Communities Project (LCP), which sought information about the views and experiences of a broad range of northern Alberta residents concerning their present post-secondary training and education opportunities. The study addresses an acknowledged gap in such information in relation to Canada in comparison with other OECD countries.

Results are based on input from 165 individuals, obtained through written surveys (some completed by the researchers in face-to-face exchanges with the respondents), interviews, discussions, and observations, conducted with full-time or part-time residents of the study communities during 2007 and 2008. The four northern Alberta communities studied were 
Wabasca, Fox Lake, Ft. McKay (sometimes MacKay), and Ft. Chipewyan, totaling just over 6,000 residents.

While respondents had varied backgrounds in relation to training and education, consensus emerged on several points: training in the studied communities must be flexible to be realistic; the negative emotional and economic impacts on families and individuals when they are forced to leave the local community to take training can be enormous; alternatives such as distance education may now be acceptable to and technologically feasible for many; and certain subjects (especially business-related courses, pre-employment preparation, such as safety and computer skills, trades training, and basic skills upgrading programs in essential skills such as math, English, writing, and life skills) were of broad interest to these residents.

The LCP was cautioned that future programming inspired by this research should avoid mistakes made by others in relation to northern learners and their local realities: not considering students' preferences for programming, employing inappropriate technologies, failing to provide adequate orientation and support to the learning system, and failure to use existing, proven delivery models.

\section{Introduction}

The province of Alberta has benefitted greatly from the resources booms of the last thirty years (Alberta Finance and Enterprise, 2008a). Based on revenues primarily from energy (in conventional oil and oil sands), Alberta has generated the highest provincial growth rate in Canada, the lowest unemployment rate, and an accumulated surplus (as of 2008) of approximately \$16 billion (Alberta Finance and Enterprise, 2007d, 2007e, 2008b, 2008c, 2008d, 2008e).

Alberta is also socially distinct in Canada with educational and social implications in its uniqueness. The province has the lowest average age of any province (the median in 2006 was 36.0 years; for Canada, it was 39.5 years); its senior population (65 years and over) is the lowest in Canada at 10.6\% (Canada, 13.7\%); the average age of Alberta's Aboriginal population was 25 in 2006, whereas for non-Aboriginals it was 36 (Alberta Finance and Enterprise, 2007a, 2007b, 2007c, 2007f); the Aboriginal population (defined as "people [who] reported Aboriginal identity (First Nation, Métis or Inuit)" grew 45\% from 1996 to 2006, as compared to a non-Aboriginal population growth rate of $8 \%$ (Canada's Aboriginal population, 2008).

In response to these challenging realities, Alberta provides a range of training and education opportunities for its residents. The province has 20 public post-secondary institutions, comprising 14 public colleges, four universities, and two technical institutes. Distance education is supported in several ways: the intent and policy of Campus Alberta (Alberta Advanced Education and Technology, 2002), and the Roles and Mandates Policy Framework (Alberta Advanced Education and Technology, 2007) assure that any course available in any Alberta institution will be open to enrollment by all Albertans; SuperNet, the broadband network, brings high-speed Internet access to large areas of the province; eCampusAlberta specifically promotes the distance learning 
offerings of Alberta post-secondary institutions; and Athabasca University specializes in distance delivery of university-level undergraduate and graduate training throughout the province and across Canada.

This study was conducted under the aegis of Athabasca University's Learning Communities Project (LCP), which commenced in 2006 as the Rural and Remote Learner Project. The project was designed to determine how educational programs and services might be improved and extended in rural and remote communities and oil sands work camps in northern Alberta. LCP was funded initially by a donation from a senior official of a major oil sands developer. As it proceeded with managing the project, Athabasca University contributed development and research expertise and services; in early 2009, the project became known simply as Learning Communities with a focus extending beyond oil sands and northern communities to all remote areas of the province.

This report concerns findings in Alberta's north in relation to the initial focus of the LCP. It addresses the following question: In an era of increasing availability of online learning, what are the preferences of Alberta's northern residents for education and training offerings, including delivery models? The study was intended to address this question by examining the views and experiences of residents of four northern communities: Fort Chipewyan, Fort McKay, Fox Lake, and Wabasca. Data were drawn from federal and provincial statistical sources and from interviews conducted by staff of LCP with, and written responses from, citizens of the selected communities.

\section{Background}

As will be discussed below, Canada has historically experimented with innovative approaches to education and training for distributed (often isolated from educational opportunity) populations; the fact that "Canada's Open University," Athabasca University, is located in Alberta is evidence of this province's commitment to non-traditional educational delivery.

Occasionally, however, mixed signals have been sent in Canada about the importance of these efforts. In 2002, the Association of Canadian Community Colleges (ACCC, 2002) in response to a federal government call for more innovation from education providers responded that colleges were already "widely accessible and well placed to support community, economic, social, and cultural development" (ACCC, 2002, slide 2). Perhaps proving the government's point, the Association made only one mention of possible need for access from remote areas to postsecondary opportunities: "[the system might improve access] by expanding capacity and access to distance learning with the goal of eliminating the gap between the have and have nots, especially those individuals living in remote or isolated communities" (ACCC, 2002, slide 4).

This study was piqued in part by the growing concern in Canada about the lack of relevant information on access nationally to education and training. In the Organization for Economic Cooperation and Development's (OECD) fall 2007 annual Education at a Glance report, Canada failed to provide information on 57 of 96 indicators (almost 60\%), the worst performance of any 
member country. As a result, in early 2008, the Director General of the Council of Ministers of Education Canada began consultations with Statistics Canada to develop a strategy for better collection and reporting of data for all education sectors. Universities, for their part, began work on a common set of data and reporting criteria, measuring such basics as student enrollment, faculty numbers, class sizes, and graduation rates (Charbonneau, 2008).

The OECD disappointment followed other embarrassments that profiled the lack of basic data about educational access in Canada. In 2003, Canada's premiers created a Council of the Federation (2006), in part to address several problems the country recognized in relation to its trading partners. These problems included the comparatively low levels of post-secondary training (especially at the graduate level), the lack of employer involvement in worker training, and the need for investment in research. Results were not immediately apparent, however: in 2007, Canada was called a "land of mediocrity" in a report that recounted the country's low level of worker literacy, failure to take advantage of the potentials of proven training technologies, and falling levels of professional creativity (Scoffield, 2007).

However, a lack of awareness of the needs for educational innovation to benefit more remote residents is not unique to Canada. In a 2001 paper discussing the evolution of adult education in Australia, Tennant and Morris (2001) did not mention the term "distance" or "distance education" at all, though the paper includes discussion of demographic and workplace changes, the role of the state in the provision of adult education, the emerging global knowledge economy, and vocational and non-vocational issues in adult and community education, including the issue of access (p. 2). On the other hand, Tapsall (2001), also writing from Australia, vividly describes the global "bandwagon" for "cyberspace solutions," which he concludes too often "marginalise[s] the traditional emphasis within distance education on ... the provision of opportunities for the socially disadvantaged" (p. 35).

In 2003, a Scottish report by Osborne shed some light on the problem of access from an operational perspective. He identified a range of initiatives colleges could use to increase access and encourage enrollments, including prior learning assessment and recognition (PLAR), open and distance learning policies, and use of information and communications technologies (p. 43). In his paper, Osborne acknowledged Canada's leadership in two areas related to enhanced flexibility: PLAR and transfer credit arrangements.

Some of the literature on flexible access cites specifically the needs of Aboriginal residents of remote communities (although the needs of any specific ethnic group were not a focus of this study, Aboriginals constitute a high proportion of residents of Canada's northern communities, including the communities studied here) (Association of Canadian Community Colleges, 2005; Census of Canada, 2008). McMullen and Rohrback (2003) reported being disappointed that while distance education has the capability to provide educational opportunities for Aboriginal students, "To date, distance education has failed to meet this ability" (p. 6). They cited various program failures, including ignoring the needs of the student, the salient characteristics of the environment, and predictable barriers; not considering students' learning styles and expectations; failing to recognize local political expectations; and reliance on unreliable delivery and 
communications technologies (pp. 6-7). Overall, the writers charge, few Canadian educational institutions or directors of education know about, or emulate, the successful programs and models, domestic and foreign, that might result in more successes with presently marginalized populations (p. 9).

Despite the above criticisms, some potentially useful Canadian models for serving isolated people have emerged from previous studies. From 1987 to 1989, the Keewatin Region, which was then part of the Northwest Territories (NWT), offered upgrading, General Educational Development (GED) preparation, life skills, and pre-employment training via PLATO computer-assisted learning in seven adult learning centres throughout the region (Fahy, 1989). While the project reported successes in skills acquisition, participation was limited in this pre-Internet era by the requirement for students to attend on-site at computer-equipped community learning centres.

Nevertheless, the project demonstrated technology-based delivery could be effective in the North. Another successful project in northern Canada, described by Gruber and Coldevin (1994), was intended to provide accelerated management training to local people training as administrators, prior to the creation of the northern territory of Nunavut in 1999. The project reiterated the point made by McMullen and Rohrbach concerning the relatively low impact of distance education to date: "[D]istance education has made relatively few inroads into Inuit settlements across the Canadian North" (Background and project rationale, 93 ). In this project, a total of 76 participants completed business and management training using satellite video transmissions, telephone/fax interaction, community learning groups, local facilitators, and specifically designed study materials in workshops delivered to six communities in three Arctic regions (Workshop design, If 1). Positive and encouraging results included "as much or more" learning than was expected (Overall impact, II 2), employer perceptions of greater self-confidence among trainees (II 3), and agreement by $90 \%$ of participants that the program should be offered again (II 4).

In another study, Knight and Tobin (2002) describe a successful project intended to enhance literacy and numeracy of Northwestern Ontario residents. The participants (primarily native females under forty years of age, described as "severely [economically] limited" by their need for upgrading) had a "positive experience" in the six to eight week program. According to the report, the delivery medium, audiographic teleconferencing (audio plus video), provided the immediacy of visual contact and created "increased rapport" between participants and instructors (p. 1). While complex and costly, experiences such as the above show that projects emphasizing technology to address accessibility can reduce barriers and can prove attractive to residents of remote communities.

In 2001, the Conference Board of Canada conducted case studies of the use of digital learning technologies in ten Northern communities across Canada (Greenall \& Loizides, 2001). The case studies identified some barriers to the use of learning technologies, including problems with highspeed Internet access, lack of local computer and Internet expertise, inexperienced instructors, and unreliable infrastructure elements. Nevertheless, the report concluded optimistically that technology provided residents with “... opportunities to enhance their skills and improve employment prospects" (p. ii), and that residents were “... embracing the potential of technologies 
for learning so members can both develop and be in a position to take advantage of economic opportunities." The report continued, "Aboriginal educators and economic development practitioners are developing and implementing creative and innovative initiatives to promote the achievement of Aboriginal 'digital opportunities"' (p. i).

These efforts at making learning opportunities more available can be highly economically successful, especially for Native people. Walters, White, and Maxim (2004) report that both male and female Aboriginals earn significantly more than other minorities when they possess postsecondary credentials; that male Aboriginals are at the top of the earnings hierarchy, compared with all post-secondary graduates; and that Aboriginals, both males and females, have better employment prospects if they have graduated from a trades or college program than from a university program if they do not return to reserves where there are (usually) fewer employment opportunities (p. 296). Aboriginal people are evidently beginning to recognize these facts: Statistics Canada (2008) reports that while the participation rate of Aboriginals in university-level programs was significantly lower than for non-Aboriginals, “... differences between the Aboriginal and non-Aboriginal population participation rates were not significant for college and for other types of institution" (Table 3, ๆ 1). As noted by others (Malatest and Associates, 2004), "Aboriginal student [post-secondary] enrollment rates are growing substantially faster than those of other demographic groups, albeit from a very low base" (p. 5).

Finally, the need for innovative delivery of post-secondary education and training in Northern Alberta is indicated by past enrollment trends. According to government data, total public postsecondary enrollments rose $10.6 \%$ in Alberta, from 124,432 to 137,676 FLEs (full-load equivalents), during the period 2001-2002 to 2006-2007 (Figure 1). However, over that period, there were other trends:

- Enrollments at the colleges that serve Alberta's northern regions fell an average of over $11 \%$ (in one northern institution, the decline was almost 27\%);

- Enrollments at public colleges elsewhere in the province remained almost constant (they increased $0.6 \%$ );

- University enrollments increased by $13.9 \%$ province-wide;

- The two institutes of technology increased enrollments by $15.7 \%$;

- Athabasca University increased its enrollment by $38.7 \%$, all at a distance. (During the six years previous to the study, Athabasca's rate of growth was from 2.6 to 57 times greater than that of Alberta's other three conventional universities.) 


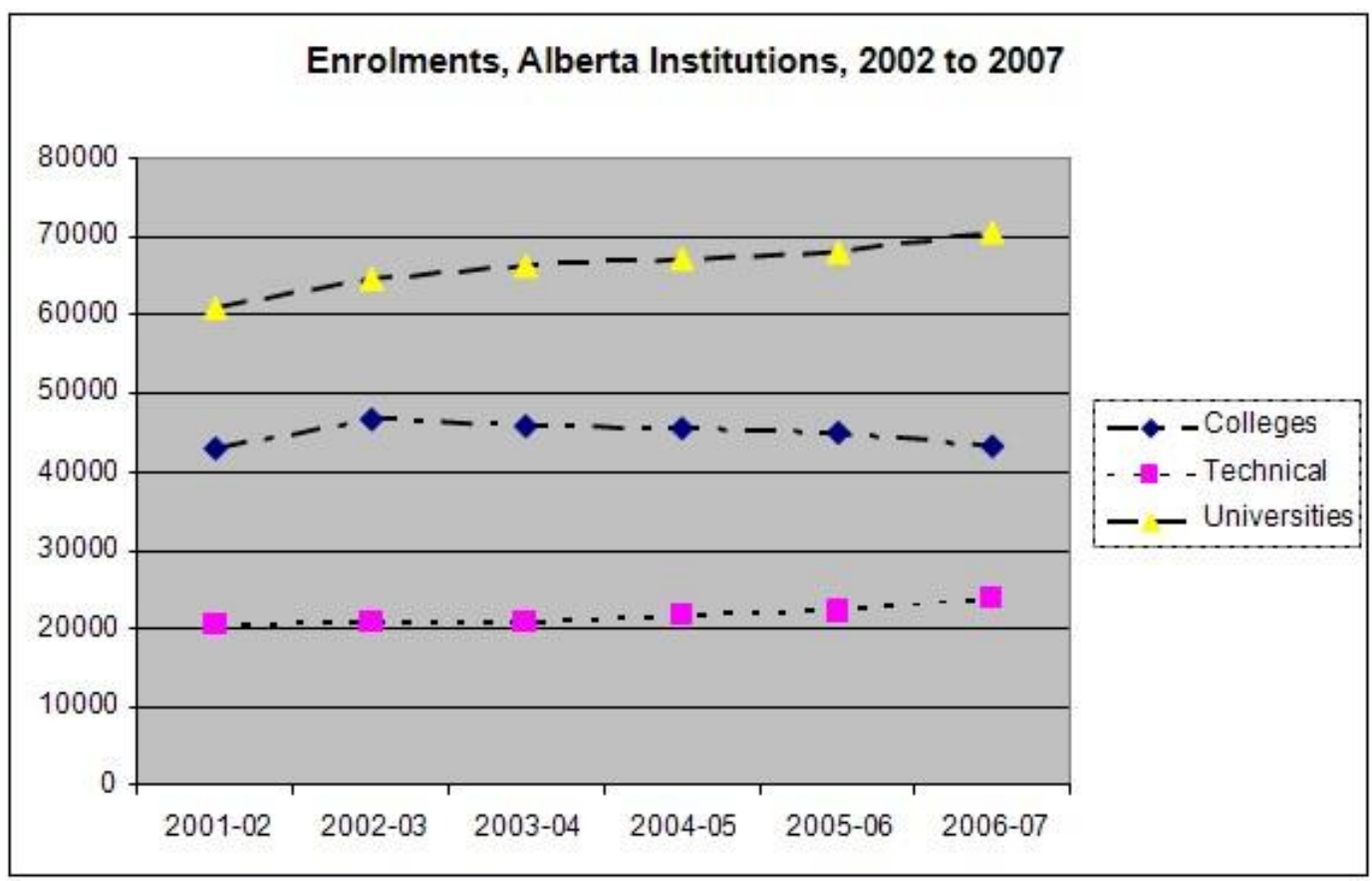

Figure 1: Fulltime-equivalent enrolments (FLEs), all Alberta post-secondary institutions, $2002-2007$.

In summary, post-secondary education appears to be a promising route for remote residents, especially those who wish to continue to reside in their communities for as long as possible during training. While some successful models of community-based training and education exist, there have also been problems with unsuccessful strategies, lack of support, poor technology selections, and a general lack of consultation with those expected to participate.

This study, focusing on the degree to which present online offerings and supports are meeting the stated preferences of residents of Alberta's remote communities, appears likely to add importantly to the picture formed by previous reports and to update and confirm the literature on the educational and training preferences and learning experiences of remote residents in an era of the emergence - even ascendance - of technology-based learning.

\section{The Study}

\section{Purpose}

The study addressed the following question: With the increasing availability of online learning, what are the preferences of Alberta's Northern residents for education and training offerings, including delivery models? The study addressed this question by examining the views of residents of four northern communities: Fort Chipewyan, Fort McKay, Fox Lake, and Wabasca (Figure 2). Data were drawn from federal and provincial statistical sources and from interviews with and written responses from residents of the selected communities. 


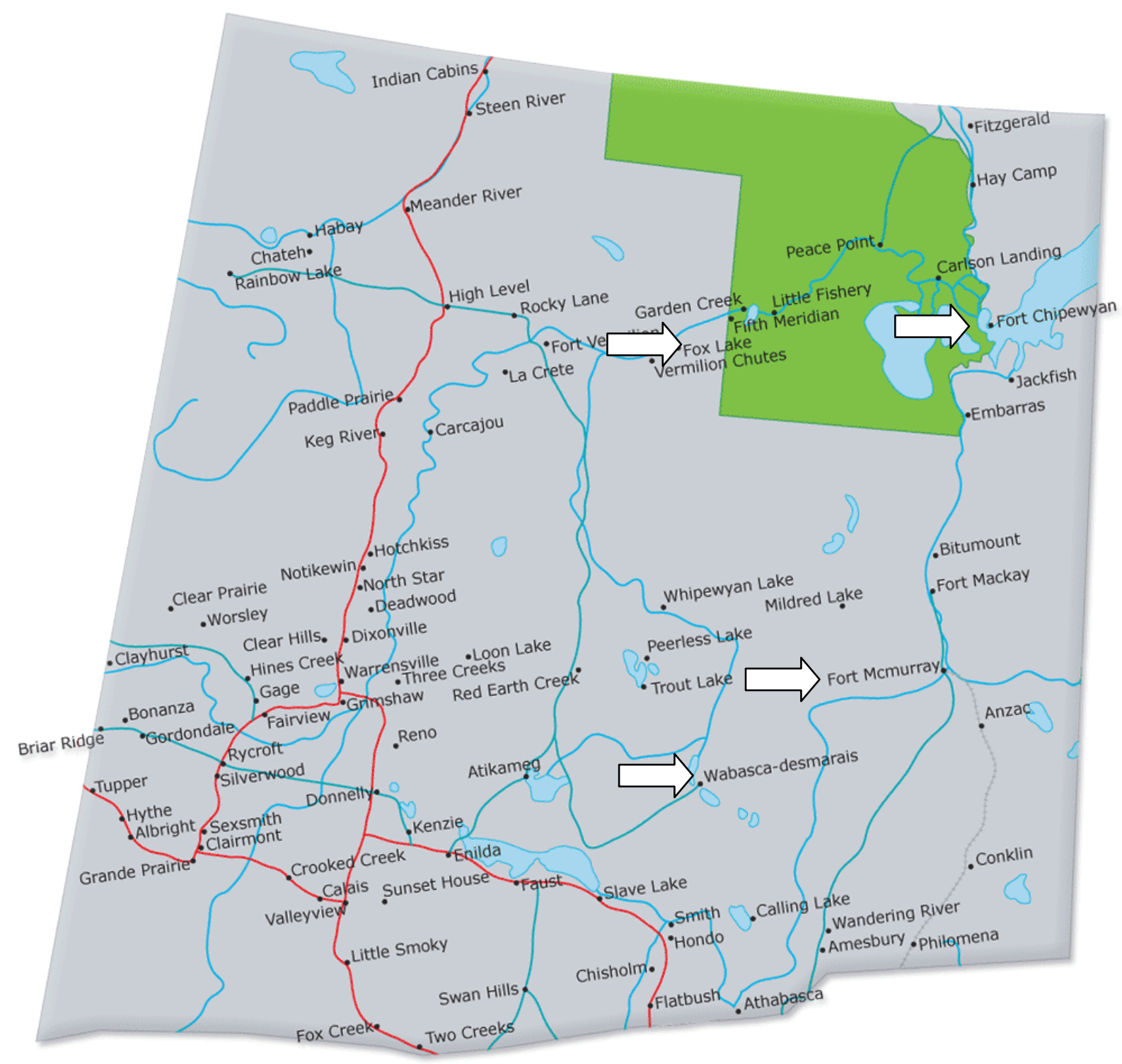

Figure 2: Location of study communities, Alberta, Canada.

\section{Some Demographic, Educational, and Economic Facts about the Study}

\section{Communities}

The four study communities are compared in the following table based on some basic educational and economic descriptors. 
Table 1

Demographic, Educational, and Economic Descriptors of the Target Communities

\begin{tabular}{|c|c|c|c|c|c|}
\hline Descriptors & $\begin{array}{l}\text { Fox } \\
\text { Lake }\end{array}$ & $\begin{array}{l}\text { Ft. } \\
\text { Chip* }\end{array}$ & $\begin{array}{ll}\text { Ft. } & \text { McKay } \\
(2006) & \end{array}$ & Wabasca & Alberta \\
\hline Population (2006) & 1,753 & 915 & 521 & 2,847 & $3,290,350$ \\
\hline $\begin{array}{l}\# / \% \text { of participants in the } \\
\text { study }\end{array}$ & $47 / 28 \%$ & $49 / 30 \%$ & $17 / 10 \%$ & $52 / 32 \%$ & \\
\hline \multicolumn{6}{|l|}{$\begin{array}{l}\text { Education }(15+\text { years of } \\
\text { age })\end{array}$} \\
\hline - No certificate or diploma & $89 \%$ & & $66.3 \%$ & $63.0 \%$ & $23 \%$ \\
\hline - Apprenticeship or trade & $1 \%$ & & $6.3 \%$ & $7.4 \%$ & $11 \%$ \\
\hline - High school diploma & $6 \%$ & & $17.5 \%$ & $14.9 \%$ & $26 \%$ \\
\hline - Unemployment rate & $19.7 \%$ & & $18.0 \%$ & 15.1 & $4.3 \%$ \\
\hline - Participation rate & $34.7 \%$ & & $61.7 \%$ & 61.3 & $74.0 \%$ \\
\hline \multicolumn{6}{|l|}{ Income $(2005)$} \\
\hline - Median, census families & $\$ 22,592$ & & $\$ 52,736$ & $\$ 42,926$ & $\$ 73,823$ \\
\hline $\begin{array}{l}\text { - Median, fulltime } \\
\text { employed }\end{array}$ & $\$ 23,584$ & & $\$ 44,384$ & $\$ 36,093$ & $\$ 43,964$ \\
\hline - Median, married couples & $\$ 41,600$ & & $\$ 72,192$ & $\$ 55,917$ & $\$ 83,046$ \\
\hline - Median, common law & $\$ 19,520$ & & $\$ 64,000$ & $\$ 45,748$ & $\$ 67,184$ \\
\hline - Median, lone parent & $\$ 11,744$ & & $\$ 35,968$ & $\$ 25,785$ & $\$ 40,397$ \\
\hline
\end{tabular}

Source: http://www12.statcan.ca/english/census06/data/profiles/community/Index.cfm?Lang=E

*Information for Fort Chipewyan was not separate from the general census data for the Wood Buffalo region, including Fort McMurray, an area of over 51,000 people.

Table 1 illustrates the fact that these four communities were not homogeneous: education and training levels were lower in the target communities, but, outside of Fox Lake, residents held more apprenticeship and trades credentials; the overall unemployment rate was higher in these Northern communities taken together, but the labour-market participation rate was considerably higher in Ft. McKay and Wabasca than in Fox Lake. Further, Ft. McKay residents had notably better incomes than the other communities - higher in the case of the median incomes for the fulltime employed than the average for all Albertans. As well, the median income of married couples in Ft. McKay was nearly equal to the median family income for the province. (Ft. McKay has economic advantages due to the services it provides to nearby oil sands companies.)

\section{Rationale}

To address how well Alberta's current educational offerings meet the preferences of the communities' residents, the study employed written surveys (some completed by respondents independently online, others completed by researchers during face-to-face contacts in the study communities). Interviews were conducted with full- and part-time residents during visits to the communities in 2007 and 2008. 
While every community member's input was invited and welcomed (announcements of the researchers' presence and purposes were circulated prior to their arrival, and methods to forward comments after the researchers' departure were provided), some individuals in each community were sought out, based on their positions in the community or on the recommendations of others. These methods resulted in input from a total of 165 residents of the four communities (see Table 1 for distribution of responses).

The study focused on the current patterns of enrollment in the selected communities and on the participants' self-reported learning experiences and preferences, including views of residents about both present program content and available delivery formats. Data from Alberta Advanced Education and Technology (2008) from the COGNOS database and information from colleges actively programming in the region provided present and historical enrollment patterns.

\section{Focus, Purpose, and Processes}

In the four Northern communities studied, technologies such as SuperNet and administrative and policy initiatives such as Campus Alberta and eCampusAlberta were expected to provide local alternatives to traditional campus-based education and training. These communities represent a range of typical northern Canadian settlements in mixed culture and demographics, economic and social structures, and relative geographic isolation (Table 1).

To determine the degree to which the provisions for post-secondary education and training in these communities meet the stated expectations and interests of the residents, the researchers reviewed available data on post-secondary registration rates, interviewed students and potential students, and consulted face-to-face with community members (including employers and representatives of various government and social services). Two researchers visited each community together, allowing them to compare their observations and interpretations. The study attempted to be blind in relation to participants' ethnic or racial backgrounds, except in providing multiple avenues for participation. The study used a combination of methods (written and oral), face-to-face contact with respondents in the communities, and ongoing contact and interaction with the respondents and the communities over time (including seeking out individuals recommended by others to invite their participation) to assure the results were rooted in the current views of a range of actual or potential students and to provide access for anyone wishing to participate.

Interviews were conducted while researchers were present in the communities; as well, the researchers left copies of the survey form for anyone who might wish to complete and return it later. In some cases, the researchers completed the surveys for residents while speaking with them (with their awareness and permission). The purpose was to determine the experiences of respondents with formal institutional learning, including both content and delivery models. The question was whether present offerings might use technology to more satisfactorily enhance accessibility and choice for Northern residents. 


\section{Ethics}

The proposal for this research was reviewed by the Athabasca University Research Ethics Board (REB) in late 2008 and approved in December 2008. It was emphasized in the ethics proposal that this research was designed to gain information, not to provide advice, and that the primary stance of the researchers throughout the process was to listen and record, obtaining the broadest possible input from the target communities.

\section{Findings}

The face-to-face surveys, including interviews, resulted in articulation of the following common themes and concerns:

1. Northern residents preferred to remain in their home communities for post-secondary training. McMullen (2004) previously reported that this preference along with the lack of financial support of a nearby delivery institution and the lack of role models were the greatest barriers to post-secondary participation of northerners. Repetition of this finding, in light of technological advances that make it more realistic in relation to learning, confirms both its enduring importance to residents and its feasibility.

2. Supportive of the above, a great majority of respondents reported access to a computer and felt they possessed sufficient computer skills to learn online. Whether those without broadband experienced this as a barrier to access was not addressed.

3. Supportive of community-based learning, over forty percent of respondents said their preferred mode of learning was "computer, Internet."

4. Not surprisingly, jobs, inconvenient timing and location of courses, and family responsibilities were the primary barriers to enrolling in or, in the past, completing programs.

5. Many respondents were concerned about financing their learning while working. (Delivery models were expected to assure that learning and work could coexist.)

6. More literacy programming is needed, particularly English conversation for speakers of native languages. Lack of conversational skills in English mainly affected older, native residents, but there were also increasing numbers of non-native immigrant speakers of English in these communities who required enhanced language and literacy skills.

7. Local colleges were generally well respected; along with the community library and the Internet, local college staff members were seen as good sources of information on educational programming, careers, and training.

8. About half of the residents who participated in the survey had engaged in training of some kind, and a majority reported the experience had been useful. (This suggests the respondents represented those already familiar with and committed to formal institutional learning.)

9. University and college courses, work-related training, parenting, and safety were primary areas of interest; business management, life skills, basic math and English, music, languages, advanced software, and Bachelor of Commerce were others. 
10. PLAR was thought to be relevant by about three-quarters of the respondents. (Taylor, Friedel, and Edge [2009] reported that lack of PLAR recognition was a common experience of youth in the North, especially Aboriginals.)

\section{Details on Educational Skills and Experiences}

The following table shows information about educational experiences and resources, as reported on the surveys.

Table 2

Combined Results, Educational Experiences, Interests, Skills (Ranked)

\begin{tabular}{|l|l|l|l|l|l|}
\hline Survey question & $\begin{array}{l}\text { Fox } \\
\text { Lake } \\
(\mathbf{n = 4 7 )}\end{array}$ & $\begin{array}{l}\text { Fort } \\
\text { Chip } \\
(\mathbf{n = 4 9})\end{array}$ & $\begin{array}{l}\text { Fort } \\
\text { McKay } \\
(\mathbf{n = 1 7}\end{array}$ & $\begin{array}{l}\text { Wabasca } \\
(\mathbf{n = 5 2})\end{array}$ & $\begin{array}{l}\text { Total } \\
(\mathbf{n = 1 6 5})\end{array}$ \\
\hline Can you use a computer? & $85 \%^{*}$ & $96 \%$ & $94 \%$ & $94 \%$ & $\mathbf{9 2 \%}$ \\
\hline Do you have access to a computer? & 83 & 88 & 88 & 92 & $\mathbf{8 8 \%}$ \\
\hline Do you have a computer in your home? & 81 & 84 & 88 & 90 & $\mathbf{8 6 \%}$ \\
\hline Is computer access convenient? & 81 & 73 & 88 & 85 & $\mathbf{8 2 \%}$ \\
\hline $\begin{array}{l}\text { Would you like more information about } \\
\text { PLAR? }\end{array}$ & 66 & 76 & 65 & 58 & $\mathbf{6 6 \%}$ \\
\hline Have you taken a college course? & 57 & 61 & 71 & 64 & $\mathbf{4 9 \%}$ \\
\hline $\begin{array}{l}\text { Is prior learning assessment and } \\
\text { recognition of interest? }\end{array}$ & 68 & 63 & 0 & 62 & $\mathbf{5 8 \%}$ \\
\hline $\begin{array}{l}\text { Have you ever taken a course on a } \\
\text { computer? }\end{array}$ & 30 & 49 & 18 & 79 & $\mathbf{4 4 \%}$ \\
\hline
\end{tabular}

*Proportion of "yes" replies to these questions.

From the above came the following indications of the learning experiences and readiness of the respondents:

1. Very high numbers of residents reported they could use a computer, had a computer in their home, or had convenient access to one.

2. Almost half had taken a course of some kind on a computer.

3. About half had previously taken a college course.

4. Two-thirds were interested in more information about prior learning assessment and recognition (PLAR).

5. The following table combines the data from the four communities regarding previous education and training patterns. 
Table 3

Combined Results, Previous Education, Present Training Interests

\begin{tabular}{|c|c|c|c|c|c|}
\hline Education element & $\begin{array}{l}\text { Fox } \\
\text { Lake } \\
(n=47)\end{array}$ & $\begin{array}{l}\text { Fort } \\
\text { Chip } \\
(n=49)\end{array}$ & $\begin{array}{l}\text { Fort } \\
\text { McKay } \\
(n=17)\end{array}$ & $\begin{array}{l}\text { Wabasca } \\
(n=52)\end{array}$ & $\begin{array}{l}\text { Total } \\
(n=165) \\
\%\end{array}$ \\
\hline \multicolumn{6}{|l|}{ Courses, programs most wanted } \\
\hline Accounting & & 1 & 2 & 2 & $3 \%$ \\
\hline Business management, admin. & 14 & 14 & 3 & 19 & 30 \\
\hline Computer skills, computer training & 1 & 4 & 1 & 4 & 6 \\
\hline Crafts, culture & 2 & 1 & 1 & 2 & 4 \\
\hline Environment & & 1 & & & 1 \\
\hline Health, nursing-related & 2 & 1 & & 1 & 2 \\
\hline Life skills & 1 & 6 & 5 & 3 & 9 \\
\hline Parenting & 1 & 4 & 2 & 4 & 6 \\
\hline Safety, First aid, H2S, CPR, WHMIS & 4 & 6 & 5 & 10 & 15 \\
\hline Sports & & & & 1 & 1 \\
\hline Technical, work-related & & 10 & 1 & & 6 \\
\hline Trades & & & & 4 & 2 \\
\hline Transportation, machine operation & & 1 & & & 1 \\
\hline Upgrading, GED & 13 & 16 & 5 & 30 & 39 \\
\hline College-, university-level courses & 3 & 2 & & 1 & 4 \\
\hline \multicolumn{6}{|l|}{$\begin{array}{l}\text { Delivery model of training previously } \\
\text { taken }\end{array}$} \\
\hline Teacher-conducted & 30 & 30 & 11 & 38 & $66 \%$ \\
\hline Computer-based & 14 & 24 & 8 & 23 & 42 \\
\hline \multicolumn{6}{|l|}{ Student-perceived barriers to learning } \\
\hline Job & 25 & 31 & 7 & 35 & $59 \%$ \\
\hline Family & 14 & 20 & 6 & 20 & 36 \\
\hline Timing & 24 & 24 & 8 & 24 & 48 \\
\hline $\begin{array}{l}\text { Location (student's own, or training } \\
\text { site) }\end{array}$ & 9 & 12 & 8 & 15 & 27 \\
\hline \multicolumn{6}{|l|}{$\begin{array}{l}\text { Reasons for not taking or not } \\
\text { completing previous training }\end{array}$} \\
\hline & 6 & 12 & 5 & 20 & $26 \%$ \\
\hline
\end{tabular}




\begin{tabular}{|l|l|l|l|l|l|}
\hline Not offered at a convenient time, place & & & & & \\
\hline Desired course not offered & 4 & 14 & 5 & 10 & $\mathbf{2 0}$ \\
\hline Cost (computer, & 1 & 3 & 0 & 4 & $\mathbf{4}$ \\
\hline $\begin{array}{l}\text { Needed } \\
\text { broadband) not available }\end{array}$ & & & & & $\mathbf{5}$ \\
\hline & & & & & \\
\hline Preferred method of learning & 21 & 35 & 15 & 26 & $\mathbf{5 9 \%}$ \\
\hline Teacher, in a classroom & 16 & 23 & 13 & 17 & $\mathbf{4 2}$ \\
\hline Computer, Internet & 6 & 12 & 5 & 10 & $\mathbf{2 0}$ \\
\hline Video & 4 & 10 & 0 & 5 & $\mathbf{1 2}$ \\
\hline TV & & & & 7 \\
\hline
\end{tabular}

From the above the following conclusions were drawn:

1. Three-quarters of the respondents reported positive previous learning experiences. (This was seen as an indication that the respondents were already learning-oriented; they were not necessarily highly schooled, however, as shown by the next two points.)

2. Upgrading (including GED and specific subjects such as math and English) were of greatest interest; next were business management and administration, followed by safetyrelated subjects.

3. Trades and technologies training were mentioned in every community by both employers and others (often in the context of "work-related" training).

4. While most respondents preferred a teacher-led learning experience, almost half (42\%) were open to computer-based learning.

5. In the interviews, job was the most often mentioned barrier to further training, followed by the timing and location of training opportunities, and family issues.

6. Training not offered at a convenient time was the most often discussed reason for nonparticipation. Lack of availability of desired courses was the next most often mentioned barrier.

\section{Discussion and Conclusions}

This study used enrollment patterns and trends and non-random sampling techniques (Simon \& Burstein, 1985, pp. 121-122) to determine, in a time of increasing availability of online learning, the preferences of Alberta's northern residents for education and training offerings, including delivery models. The findings suggest that if a range of upgrading, business- and employmentrelated programming (including trades) were offered locally, with both face-to-face and computer-based options that could accommodate work and family responsibilities, most of the expressed preferences of the study's respondents would be met. Most importantly, if the offerings were by distance methods only, over $40 \%$ of the respondents reported they would be open to enrolling.

Presently, while the institutions offering programs locally are respected, consulted, and attended, records show that northern residents have increasingly chosen employment over training, as 
shown by recent enrollment declines. They reported in interviews that they were less willing to interrupt their careers or seriously inconvenience themselves and their families to access formal institutional training programs. The study thus confirmed the potential viability of distance learning as an alternative for some residents, supported by the fact that respondents in all the study communities reported access to, and confidence in the use of, distance technologies located either in their homes or conveniently nearby and a willingness to learn to use technology.

In combination, some of the study's findings are suggestive of actions institutions might take and decisions policy makers might adopt to enhance their appeal to Northern Albertans and, to the degree these individuals are representative, to Northern Canadians. While a majority of the respondents indicated they had access to, and were comfortable with, computer technologies, had access to computers in their homes, or had convenient access somewhere to a computer, a minority (42\%) had actually used computers in learning. Combined with the residents' express desire to stay in their home communities for training, the flexibility and accessibility of online and distance learning might be attractive if residents knew more about this option and its workings. This interpretation is bolstered by the finding that the reason most often given by respondents for failing to enroll in or complete a program was the usual inconvenience associated with program access. A delivery methodology that reduces inconvenience, or that positively facilitates access to learning, might address a fundamental problem related to enrollment presently experienced by northerners: clashes with job, personal, and family priorities.

The task of making distance delivery a viable option in the North is complex; learners have to be shown how to be successful with online learning and distance methods of delivery. Peters (2004) has warned that "situational factors" such as employment, lack of employer support, and past (negative) experiences with formal education, can be significant in the decision by adults to engage in or avoid formal learning projects. The study demonstrates that institutions offering technology-based programs in the North need to provide relevant information on the differences between traditional and online learning; give information to employers, the community, and families about the requirements to be successful in online learning; and provide training in how to be a successful online learner.

The findings relate to historical patterns by suggesting that some new possibilities may now exist for learners in remote areas. Historically, studies have established that personal and situational factors vary in individuals and are significant for learning success (Cross, 1981); that adults have various and diverging reasons for learning (Houle, 1961; Boshier, 1971; Hough, 1984; Furst, 1986); that cognitive factors are but one of the influences on learning, others being attitudes and emotions (affect) and the quality of instruction (including delivery methods) (Bloom, 1976); and that previous preparation is likely to profoundly impact the success of subsequent learning efforts (Carroll, 1963; Bonds of Time, 2009). While the representatives of the Northern communities we studied differed on some questions, they agreed with the view that training and education must become more flexible to be compatible with adult situational factors; that personal purposes and preferences (including a people's educational history) are significant to present attitudes; that quality of content and support is expected in online programs; and that the earlier experiences of potential individual Northern learners cannot be ignored, especially as related to failures or 
disappointments (Taylor et al., 2009). Local differences aside, the consensus was that a delivery model is needed for the study communities that respects learners' needs and preferences, rather than requiring them to make most of the adjustments; that recognizes prior learning (formal and non-formal); and that is consistent and compatible with residents' personal, family, and workrelated realities.

It must be noted that the researchers were "outsiders" to the communities studied and that the research did not arise from internal priorities of the residents or of the communities themselves. While both researchers had considerable experience residing and working in the North, neither was a resident of one of the four communities. The researchers nevertheless felt that the views expressed to them, and the findings they reported, reflected the candid and honest responses of the participants, but the possible impact of their non-resident status and the possible perceptions of some residents regarding the pertinence of the research itself cannot be assessed.

Finally, and positively, it should be encouraging to present institutional education providers that the study found large majorities of the respondents had found community educational programming useful (89\%) and that they desired more of it (100\%). At $42 \%$, the minority seeking distance access is a substantial one. Serving them will increase awareness of delivery options by those not enrolled and should help inform those in face-to-face courses about possible alternatives to that form of delivery. Expanding distance offerings would help address the need confirmed by this study for "greater control over program content and delivery" in the North (Taylor et al., 2009). 


\section{References}

Alberta Advanced Education and Technology (2002). Campus Alberta - a policy framework. Retrieved October 9, 2008, from http://www.advancededucation.gov.ab.ca/pubstats/CampusPolicy/default.asp?Chapter=V ision

Alberta Advanced Education and Technology (2007). Roles and mandates: Policy framework for Alberta's publicly funded advanced education system. Available from http://www.advancededucation.gov.ab.ca/reading/policy/roleframework/Roles $\% 20$ and $\% 2$ 0Mandates\%20Policy\%20Framework\%20FINAL.pdf

Alberta Advanced Education and Technology (2008). Adult learning: COGNOS reporting. [Online (extranet) database.] Available from https://phoenix.edc.gov.ab.ca/login/default.asp

Alberta Finance and Enterprise (2007a). 2006 census highlights: Population and dwelling counts. Available from http://www.finance.gov.ab.ca/aboutalberta/census/index.html

Alberta Finance and Enterprise (2007b). 2006 census highlights: Age and sex. Available from http://www.finance.gov.ab.ca/aboutalberta/census/2007_0717_2006_age_sex.pdf

Alberta Finance and Enterprise (2007c). 2006 census highlights: Aboriginal peoples. Available from http://www.finance.gov.ab.ca/aboutalberta/census/2008_0118_Aboriginal_release.pdf

Alberta Finance and Enterprise (2007d). Alberta Heritage Savings Trust Fund 2008-09 second quarter update. Available from http://www.finance.gov.ab.ca/business/ahstf/index.html

Alberta Finance and Enterprise (2007e, November 20). Heritage Fund to receive injection from surplus. Available from http://www.finance.gov.ab.ca/business/ahstf/index.html

Alberta Finance and Enterprise (2007f). Information from the 2006 census of Canada: Age and sex. Available from http://www.finance.gov.ab.ca/aboutalberta/census/2007 $0717 \quad 2006$ age sex.pdf

Alberta Finance and Enterprise (2008a.) Highlights of the Alberta economy. Available from http://www.albertacanada.com/documents/SP-EH_highlightsABEconomyPres.pdf

Alberta Finance and Enterprise (2008b, June 24). Alberta Heritage Savings Trust Fund 2007-08 annual report (news release). Available from http://alberta.ca/ACN/200806/23865BB504BD6-ABFC-B59F0AD211025CB9B96C.html 
Alberta Finance and Enterprise (2008c). Current economic indicators by province (for the week $\begin{array}{llll}\text { ending } & 25 & \text { July } & \text { Available }\end{array}$ http://www.finance.gov.ab.ca/aboutalberta/economic_bulletins/current_economic_indicat ors.pdf

Alberta Finance and Enterprise. (2008d). Labour force developments: September 2008.

Available from http://www.finance.alberta.ca/aboutalberta/labour_force/2008/2008_09_developments.pd $\underline{\mathrm{f}}$

Alberta Finance and Enterprise (2008e). Budget 2008. Available from http://www.finance.alberta.ca/publications/budget/budget2008/fiscal.pdf

Association of Canadian Community Colleges. (2002). Colleges and institutes and Canada's innovation strategy. Retrieved October 9, 2008, from www.accc.ca/ftp/zGovRelations/2002Innovation.pdf

Association of Canadian Community Colleges (2005). Meeting the needs of Aboriginal learners: An overview of current programs and services, challenges, opportunities and lessons learned. Retrieved December, 17, 2008 from http://www.accc.ca/ftp/pubs/200507_Aboriginal.pdf

Bloom, B. S. (1976). Human characteristics and school learning. Toronto: McGraw-Hill Book Co.

Bonds of time. (2009, January 10). The Economist, 390(8613), 66.

Boshier, R. (1971). Motivational orientations of adult education participants: A factor analytic exploration of Houle's typology. Adult Education Quarterly, 21(2), 3-26.

Canada's Aboriginal population has broken the one-million mark. (2008). Alberta Sweetgrass. Retrieved November 12, 2008, from http://findarticles.com/p/articles/mi 6964/is 2 15/ai_n28489110

Carroll, J. B. (1963). A model of school learning. Teachers College Record, 64, 723-733.

Census of Canada. (2008). Aboriginal release. Available from http://www.finance.gov.ab.ca/aboutalberta/census/2008_0118_Aboriginal_release.pdf

Charbonneau, L. (2008, March.) Two new projects aim to fill gap in PSE [post-secondary education] data. University Affairs, 31-32.

Council of the Federation. (2006). Competing for tomorrow: A strategy for postsecondary 
education and skills training in Canada. Retrieved July 12, 2007, from http://www.councilofthefederation.ca/pdfs/PSE\%20Strategy-July-ENG.pdf

Cross, P. (1981). Adults as learners. San Francisco: Jossey-Bass.

Fahy, P. J. (1989). External evaluation of PLATO cluster installations in seven Arctic Communities, July, 1987, to June, 1989 (Unpublished report). Keewatin Region Education Authority, Arctic College.

Furst, E. J. (1986). An interpretation of the Boshier-Collins cluster analysis testing Houle's typology. Adult Education Quarterly, 36(4), Summer.

Greenall, D., \& Loizides, S. (2001). Addressing Aboriginal learning needs through the use of learning technologies. Conference Board of Canada. Available from http://www.hrsdc.gc.ca/en/hip/lld/olt/Skills_Development/OLTResearch/aborig_e.pdf

Gruber, S. \& Coldevin, G. (1994). Management training at a distance for Inuit administrators: The ATII pilot project. The Journal of Distance Education, 9(2), 21-34.

Houle, C. O. (1961). The inquiring mind. Madison: University of Wisconsin Press.

Hough, M. (1984). Motivation of adults: Implications of adult learning theories for distance education. Distance Education, 5(1), 7-23.

Knight, D., \& Tobin, L. (2002). Building basic skills for adults in small rural communities. Final report to the Office of Learning Technologies, project \#99561. Thunder Bay, Ontario: Contact North.

Malatest \& Associates. (2004). Aboriginal peoples and post-secondary education: What educators have learned. Available from http://www.millenniumscholarships.ca/images/Publications/Aboriginal_en.pdf

McMullen, K. (2004). Distance as a post-secondary access issue. Available from http://www.statcan.gc.ca/pub/81-004-x/200404/6854-eng.htm.)

McMullen, B., \& Rohrbach, A. (2003). Distance education in remote Aboriginal communities: Barriers, learning styles and best practices. Prince George BC: College of New Caledonia press. Available from http://www.cnc.bc.ca/mackenzie

Osborne, M. (2003). Policy and practice in widening participation: A six country comparative study of access as flexibility. International Journal of Lifelong Education, 22(1), 43-58. DOI: $10.1080 / 02601370304826$

Peters, V. (2004). Working and training: First results of the 2003 Adult education and training 
survey (81-595-MIE2004015). Ottawa, ON: Statistics Canada. Retrieved July 30, 2007, from http://www.statcan.ca/english/freepub/81-004-XIE/200412/aets.htm

Scoffield, H. (2007, June 13). Canada: Land of mediocrity. Globe \& Mail (globe\&mail.com). Retrieved June 14, 2007, from http://license.icopyright.net/user/viewFreeUse.act?fuid=Mzc0ODUz).

Simon, J., \& Burstein, P. (1985). Basic research methods in social science (3rd ed.). Toronto: McGraw-Hill, Inc.

Statistics Canada. (2008, November 17). Participation, graduation and dropout rates. Available from http://www.statcan.gc.ca/pub/81-595-m/2008070/6000003-eng.htm

Tapsall, S. (2001). All aboard the borderless education bandwagon. Open Learning, 16(1), 3546.

Taylor, A., Friedel, T. L., \& Edge, L. (2009). Pathways for First Nation and Metis youth in the oil sands. Canadian Policy Research Networks Research Report, April 2009. Available from http://www.cprn.org/documents/51241_EN.pdf

Tennant, M., \& Morris, R. (2001). Adult education in Australia: Shifting identities 1980 2000. International Journal of Lifelong Education, 20(1), 44-54.

Walters, D., White, J., \& Maxim, P. (2004). Does post-secondary education benefit Aboriginal Canadians? An examination of earnings and employment outcomes for recent Aboriginal graduates. Available from http://economics.ca/cgi/jab?journal=cpp\&view=v30n3/CPPv30n3p283.pdf 